\title{
Circuit
}

Musiques contemporaines

\section{A Young Person's Guide for Audiences of All Ages}

\section{Brian Current}

Volume 16, numéro 2, 2006

Musique de création et jeunes publics

URI : https://id.erudit.org/iderudit/902398ar

DOI : https://doi.org/10.7202/902398ar

Aller au sommaire du numéro

Éditeur(s)

Les Presses de l'Université de Montréal

ISSN

1183-1693 (imprimé)

1488-9692 (numérique)

Découvrir la revue

Citer cet article

Current, B. (2006). A Young Person's Guide for Audiences of All Ages. Circuit, 16(2), 69-72. https://doi.org/10.7202/902398ar d'utilisation que vous pouvez consulter en ligne.

https://apropos.erudit.org/fr/usagers/politique-dutilisation/ 


\section{A Young Person's Guide for audiences of all ages}

Brian Current

On afternoons prior to Esprit Orchestra concerts, it is gratifying to pass the telltale line of school buses lined up outside of Toronto's St. Lawrence Centre. Inside, the theatre is packed and abuzz with students from surrounding schools. Composers Alex Pauk and Alexina Louie appear on stage and speak in energetic bursts about the works being performed. The students listen to long swaths of vivid, uncompromising pieces. Ligeti, Dalbavie, Lindberg. It makes the heart glad.

As a guest composer I have participated in these educational events, which consist of live music with conversations about the works during the intervals ${ }^{1}$. Recently, I have wondered if we could push this idea further, and rather than speak about a piece before or after it is performed, create a work for narrator and orchestra where the speaker explains aspects of the music while the orchestra demonstrates in real time. The piece would explore form, rhythm, gesture, pitch, harmony, melody, texture, colour and electronic music. Moreover, it would be a musical experience as well as an educational one, with extroverted orchestral material and a narration that is presented in a way that is theatrical and engaging. Such a work is now underway. This article will discuss the motivation for writing the piece, as well as explain some of the aesthetic and ethical issues that have presented themselves thus far. Mainly, I hope to energize the dialogue between composers and new audiences. It is this interaction, I
1. See Esprit's Towards a Living Art. Lecture/demonstrations are also brought to schools on a regular basis and programs exist to encourage students to create their own compositions. 
2. These took place around Toronto, in San Francisco and in Poznan, Poland at a Murray Schafer-inspired festival of educational and interactive works called "Music and Play". believe, that will ultimately address the gap between listener expectations and compositional trends of the $20^{\text {th }}$ and $21^{\text {st }}$ century.

There are numerous role models for composers who act as a kind of guide to more difficult music. Britten's Young Person's Guide to the Orchestra comes first to mind, along with Prokofiev's Peter and the Wolf, Hindemith's Gebrauchsmusik, and Bernstein's leadership of the Young People's Concerts. The Britten in particular is well known for introducing the instruments of the orchestra to an incalculable number of students from primary to university age. It's a marvellous piece, with an accomplished set of variations and an unparalleled, high-flying finale. However, let us remember that the Young Person's Guide is now 60 years old, composed in 1946. It stops at conventional orchestration, which we know to be just the tip of the iceberg. An updated Guide would be useful to address trends common to composers since Britten's time (and some even decades before) that still confound many newcomers. Also, when we think of creative music education - in Canada and elsewhere we think of our own Murray Schafer, who is certainly an inspirational figure for the work. There is a real altruism at the heart of Schafer's output, perceptible in the choral and theatre works, but more tangible in the Gebrauchsmusik pieces such as Jonah or Epitaph for Moonlight. In the past, I have attempted to follow his example by writing two works involving participation by children in the audience: YOU ARE (1997), where the children make sounds and recite poetry in response to coloured lighting and Music by Way of You (2000), a kind of choose-your-own-adventure where the children decide where the music will go next. At the "performances" (really educational workshops ${ }^{2}$ ), I have found that the students are surprisingly enthusiastic about alternative musical ideas. They are eager to participate, and if asked, will readily perform such feats as improvising non-tonal melodic lines or, as a group, even sing in cross-fading cloud textures. The goal of this project is to build on these experiences, as well as on the Britten and other works, to expose audiences to musical ideas they may not have experienced before.

As for challenges in the writing, aside from the obvious obstacle of taking what is essentially an academic lecture and turning it into a compelling musical experience, there are two aesthetic considerations that have emerged so far. Both, I feel, are surmountable with adequate care. First, one quickly runs into a problem where the music is in danger of becoming a kind of background or soundtrack. When a narrator is present, I find a psychological shift occurs where one can easily lose focus on the music and think exclusively on what is being said. Ironically, this is quite the opposite of the main message of the piece, which is to emphasize that concert music is not a backdrop or ambient in any way. To 
counteract this, the writing alternates between narration (with simple recitativelike accompaniment) and extroverted musical outbursts ${ }^{3}$. A description of a descending texture, for example, is followed by an actual descending texture and so on. Also, the narration is inherently linked to the material itself, with the narrator saying, for instance, the-rhythm-of-the-words-I'm-speaking-right-now with the orchestra accompanying in parallel speech patterns. So long as the narration and music do not conflict, the intention is clear.

A second and more important issue is the danger of over-generalization. One must be careful not to impose subjective values on a listener's approach to a broad spectrum of contemporary music. For example, if the narrator explains that it is counterproductive to listen for a prevailing melody in a $20^{\text {th }}$ or $21^{\text {st }}$ century orchestral work, how is that listener going to approach the acres of melodically-based music composed over the last one hundred years? Or, when emphasizing the importance of "listening with a memory", how are they then going to approach, say, earlier works by Steve Reich, where remaining "in the moment" is, I think, the most thrilling way to hear the piece? Composers think quite regularly about not predisposing their audience. Many, with good reason, might consider it hazardous to bias anyone, especially young people. However, consider that these same listeners will already be predisposed by many other forces, mostly from the world of marketing. Young listeners are often told that classical music is meant to be relaxing or ambient. They also hear that a piece of music is successful only to the extent that a melody is memorable. Or they see symphony orchestras and public broadcasters incorporating more popular music into their programming in a bid to be more rebellious, which is odd since this behaviour is entirely conformist. These messages are pervasive and can be quite powerful.

The new Guide offers an alternate view, the one generally taught in composition programs in universities. To be fair, these assumptions are equally arbitrary, but are ones I believe in and hope to convey through the piece: Composers are trying to tell you what it feels like to be alive at this time and place in history, and this will sound quite different from music composed at other times and places in history. These composers are trying to build something rocksolid, that withstands the tests of time, and therefore it may take repeated listening to understand. The music is not meant to be relaxing. In fact, the history of Western music is a history of ideas - one rebellion following another - and if you are not an attentive listener, you most likely will not grasp these ideas. This is presented alongside a caveat that each piece is unique and that anything is possible. The work is not meant to predispose young audiences, but rather to offer advice to listeners (of all ages, really) on how to approach certain
3. This is nothing spectacularly innovative. Others (Stravinsky in L'histoire du soldat, for one) have solved this narrator problem in the same way. 
4. Please feel free to email comments and suggestions, in either language, to info@briancurrent.com. modernist techniques in Western concert music that audiences have traditionally found difficult to grasp.

It is, of course, necessary to tread carefully. As an added precaution, a short workshop will take place in May of 2006 before the work is completed the following season. Also, since the work describes contemporary concert music in general, I certainly welcome suggestions and comments about the text from colleagues in the new music community, now and as the work proceeds ${ }^{4}$.

Media Headquarters, an arts-documentary production company in Toronto (Le Mozart noir, Souvenir of Canada), has offered to make a DVD version of the piece intended for music teachers in public schools in Canada and elsewhere. Students who view the film will be invited to access an interactive website hosted by Esprit, where they can find out more about new music and the orchestra's activities. In the long term, the goal is to create a film and piece with the same purpose, which is to provide a window into art of composition and, by promoting an environment of thoughtful listening, help to demystifying new music for audiences of all ages. 